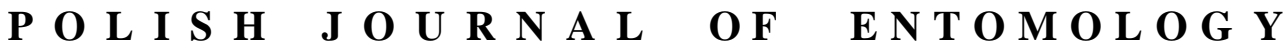

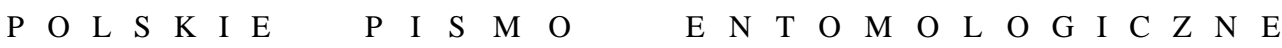

VOL. 84: 73-83

Lublin

30 June 2015

DOI: $10.1515 /$ pjen-2015-0007

\section{Hoplothrips carpathicus PELIKÁN, 1961 (Thysanoptera: Phlaeothripidae) - a new thrips species in the Polish fauna}

\author{
HALINA KUCHARCZYK ${ }^{1}$, ŁUKASZ WYROZUMSKI ${ }^{2}$ \\ Department of Zoology, Maria Curie-Skłodowska University, Akademicka 19, \\ 20-033 Lublin, Poland, e-mail: ' halina.kucharczyk@ poczta.umcs.lublin.pl, \\ ${ }^{2}$ wyrak.w@gmail.com
}

\begin{abstract}
Hoplothrips carpathicus PELIKÁn, 1961 was recorded for the first time in Poland in two localities: in the Białowieża National Park and in the Bieszczady National Park. It was captured using IBL2 screen traps at both sites. The diagnostic characteristics of the macropterous females found in Poland were compared with the micropterous holotype described in Slovakia. Key features are illustrated and data on the distribution of this species in Europe is appended.
\end{abstract}

KEY WORDS: thrips, mycophagous species, screen traps, Białowieża National Park, Bieszczady National Park.

\section{INTRODUCTION}

The order Thysanoptera is divided into two suborders: Terebrantia and Tubulifera. The latter contains only one family - Phlaeothripidae - divided into two subfamilies Phlaeothripinae and Idolothripinae. The genus Hoplothrips Amyot \& SERVILLE, 1843 belongs to the former and is represented by at least 130 species worldwide, 20 in Europe and 10 in Poland (Mound \& WALKer 1986, KuCHARCZYK 2007, VIERBERGEN 2013 and the first co-author's unpublished data). All Hoplothrips species are fungivorous and live mostly on decaying wood or in leaf litter. They feed on fungal hyphae and their maxillary stylets are narrow (2-3 $\mu \mathrm{m}$ wide), whereas species of the subfamily Idolothripinae, which ingest fungal spores, have maxillary stylets with a food canal at least 5-10 $\mu \mathrm{m}$ wide (TREE et al. 2010). Several species of this genus are colonial and polymorphic. Macropterous, 
brachypterous and apterous forms of females and males are known in their populations. Two forms - oedymerous and gynaecoid - occur in males: they are characterized by the allometry of some body parts. The biology of some species involves subsocial behaviour and male infighting (CRESPI 1986, KOBRO \& RAFOSS 2006).

Adult polymorphism and variation of features are the reason for the difficulties in identifying Hoplothrips species (Mound et al. 1976), but all of them share several similarities, which are listed in detail by MOUND \& WALKER (1986). The most important ones are: small compound eyes most often occupying about $1 / 4$ of the length of the head; 8-segmented antennae with clearly separated segments VII and VIII; usually three and four sense cones on antennal segments III and IV, respectively; parallel-sided forewings with duplicated cilia at the apex. In most of the species males have a glandular area on abdominal sternite VIII.

Hoplothrips carpathicus was described by JAROSLAV PELIKÁN in 1961 on the basis of two wingless females. They were collected on 23 June 1956 by L. LAUTERER from the bark of Fagus sylvatica LinnaEus, 1753 in eastern Slovakia (Vihorlat Mountain - $900 \mathrm{~m}$ amsl, Inner Eastern Carpathians) (PELIKÁN 1961).

On the basis of PELIKÁN's description, H. carpathicus was included in keys for the identification of European species prepared by PRIESNER (1964) and SCHLIEPHAKE \& KLIMT (1979). In the latter, H. carpathicus as well as two other species noted in Poland, Hoplothrips caespitis (UzEL, 1895) and Maderothrips (Hoplothrips) longisetis (BAGNALL, 1910), are identifiable by two sense cones on both antennal segments III and IV. KoBRO \& RAFOSS (2006) have taken into account $H$. carpathicus in a key for eight Hoplothrips species known from Norway. The identification of these species is based on a few metric characters, which are the same for both males and females. According to this key, $H$. carpathicus is distinguishable by such characters as short mediolateral seta on the pronotum $(<110 \mu \mathrm{m})$, the distance between D1 setae on tergite IX is shorter than the width of the basis of segment $X$ (tubus) and these setae are longer than $140 \mu \mathrm{m}$, antennal segment VIII longer than $75 \mu \mathrm{m}$, antennal segment III and almost always antennal segment IV with two large sense cones.

This paper supplies faunistic data on the occurrence of H. carpathicus in Poland and compares the metric characters of macropterous females found in Poland with those of the micropterous holo- and paratype described by PELIKÁN from Slovakia. The key characteristics of $H$. carpathicus are illustrated, and data on its distribution in Europe is appended. 


\section{MATERIALS AND METHODS}

Specimens of $H$. carpathicus were found at three sites in the Białowieża National Park and six sites in the Bieszczady National Park. All specimens were captured using IBL2 screen traps suspended about a metre above the ground. An aqueous solution of ethylene glycol was used in the traps. The traps at all the sites were emptied every two weeks. The materials gathered in the traps in the Białowieża Forest come from the Forestry Research Institute's collection; they were kindly donated by Prof. J. GUTOWSKI. The insects were collected between 1999 and 2001 during research into the migration of cambiophagous beetles across the border between the strict reserve and managed forests in forest compartments 374D/403B and 454C, and also during monitoring research in compartments 288A/318C (Table 1) (GUTOWSKI \& KRZYSZTOFIAK 2005).

Table 1. Data relating to the materials examined.

\begin{tabular}{|c|c|c|c|}
\hline UTM Square & $\begin{array}{c}\text { Forest compartment/ } \\
\text { Trap No. }\end{array}$ & No. of females & Collection date \\
\hline FD 84 & $288 \mathrm{C} / 318 \mathrm{~A}$ & 1 & 21.06 .2000 \\
\hline FD94 & 374D/403B & 1 & 6.06 .2000 \\
\hline FD94 & $454 \mathrm{C}$ & 2 & 22.06 .1999 \\
\hline FD94 & $454 \mathrm{C}$ & 2 & 4.07 .2000 \\
\hline FD94 & $454 \mathrm{C}$ & 5 & 18.07 .2000 \\
\hline FD94 & $454 \mathrm{C}$ & 1 & 27.06 .2001 \\
\hline FD94 & $454 \mathrm{C}$ & 1 & 11.07 .2001 \\
\hline FV 23 & trap1 (804 m amsl) & 1 & 16.07 .2013 \\
\hline FV 23 & trap $3(880 \mathrm{~m}$ amsl $)$ & 1 & 22.082013 \\
\hline FV 23 & trap 4 (912 m amsl) & 1 & 20.08 .2012 \\
\hline FV 23 & $\operatorname{trap} 5(936 \mathrm{~m}$ amsl $)$ & 12 & 20.08 .2012 \\
\hline FV 23 & $\operatorname{trap} 5(936 \mathrm{~m}$ amsl $)$ & 1 & 16.07 .2013 \\
\hline FV 23 & trap 7 (1046 m amsl) & 1 & 20.08 .2012 \\
\hline FV 15 & trap $11(785 \mathrm{~m}$ amsl $)$ & 1 & 5.08 .2013 \\
\hline FV 15 & trap $11(785 \mathrm{~m} \mathrm{amsl})$ & 3 & 23.08 .2013 \\
\hline
\end{tabular}

In 2012 and 2013 twenty screen traps were deployed in the Bieszczady NP along two trails: one from Wołosate village to Tarnica Mt. (traps 1-10) and the other from Zatwarnica to the Orłowicz Pass (traps 11-20). H. carpathicus was found at five sites along the former 
trail and at one along the latter (Table 1). In the Białowieża NP screen traps were deployed in forest communities with dominant Norway Spruce (Picea abies (LINNAEUS, 1753) KARSTEN, 1881), whereas in the Bieszczady NP traps were hung on Betula pendula RoTH, 1788 (trap 1), Picea abies (traps 4, 5), Fagus sylvatica (traps 3, 7) and Larix decidua MILLER, 1768 (trap 11) in the lower forest zone, which is dominated by Fagus sylvatica with artificial plantings of Norway Spruce and larch. After removal from the traps all specimens were preserved in 70\% ethanol and mounted in Berlese fluid or Canada Balsam for identification (MOUND \& KIBBY 1998). 35 morphological characters used by PELIKÁN (1961) and one used by KOBRO \& RAFOSS (2006) were measured for eleven specimens, the best preserved ones, collected in both study areas and compared with the measurements of the holotype.

Species were identified according to the key by KobRO \& RAFOSS (2006), and morphological analyses and the figures (Figs 1-5) were prepared using an Olympus BX 61 microscope with differential interference contrast (DIC) and an Olympus DP72 camera. The materials examined are deposited in the collection of the Department of Zoology, Maria Curie-Skłodowska University, Lublin.

\section{RESULTS}

To date 13 females of $H$. carpathicus have been collected using screen traps in the Białowieża NP and 21 in the Bieszczady NP. From all traps several specimens were collected, except trap No. 5 in the Bieszczady Mts., where 12 specimens were found (Table 1). In contrast to the micropterous holotype, all specimens known from Poland are macropterous (Fig. 1). According to the data given by PELIKÁN, some measurements of body parts and setae in the macropterous form differed from the corresponding measurements in the micropterous holotype. On average, the total body length of macropterous specimens was greater than that of the holotype. Other characters in which the holotype differs from the specimens we analysed include the length and width of prothorax (greater in the micropterous form), and the length and width of the pterothorax (larger in the winged form). In addition, the sense cones on antennal segments III and IV are longer in the macropterous form, and in some specimens there were three sense cones on antennal segment IV. The length and width of the pelta (the first abdominal tergite) were smaller in the winged form, and their pronotal mediolateral setae varied in length (Figures $3,4,5$; Table 2). 

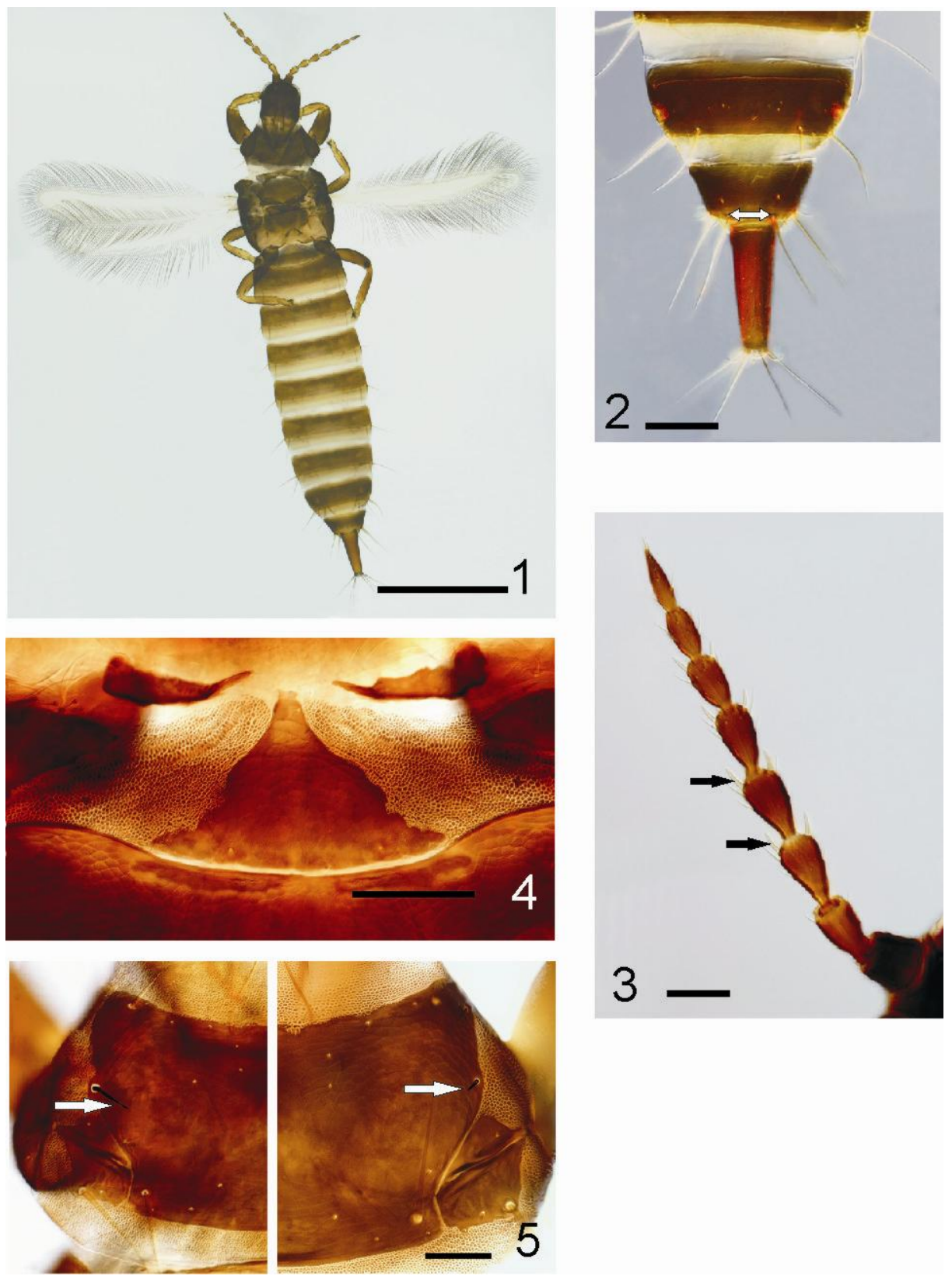

Figs 1-5. 1 - Hoplothrips carpathicus female habitus, 2 - abdominal segments VIII-X, distance between D1 setae marked, 3 - antenna, inner sense cones on $3^{\text {rd }}$ and $4^{\text {th }}$ segment marked, 4 - shape of pelta, 5 - pronotum with mediolateral seta - normal size (left), microseta (right). Scale bars: Fig. $1-300 \mu \mathrm{m}$, Figs $2-5-50 \mu \mathrm{m}$. 
Table 2. Comparison of characteristics of Hoplothrips carpathicus holotype (paratype) (H / P) and specimens collected in the Białowieża NP and the Bieszczady NP (own data, $\mathrm{n}=11$ ) (measurements in $\mu \mathrm{m}$ ). Min. - minimal value, Max. - maximal value, Aver. average value, $\pm \mathrm{SD}$ - standard deviation.

\begin{tabular}{|l|c|c|c|c|c|}
\hline \multirow{2}{*}{ Characteristics } & \multirow{2}{*}{ H / P } & \multicolumn{4}{c|}{ Own data } \\
\cline { 3 - 6 } & & Min. & Max. & Aver. & \pm SD \\
\hline Total body length & 2600 & 2500 & 3250 & 2757.3 & 217.4 \\
\hline Length of head & $290(265)$ & 210 & 250 & 242.3 & 12.1 \\
\hline Width of head & 275 & 230 & 310 & 281.8 & 24.5 \\
\hline Length of ocelli & 18 & 25 & 30 & 27.3 & 2.6 \\
\hline Length of postocular seta & $120(125)$ & 110 & 130 & 116.4 & 8.7 \\
\hline Length of antennae & $593-600$ & 545 & 635 & 597.3 & 26.4 \\
\hline Length of antennal s. I & 73 & 50 & 70 & 59.1 & 7.1 \\
\hline Length of antennal s. III & 81 & 75 & 90 & 82.7 & 5.3 \\
\hline Length of antennal s. IV & $70-73$ & 75 & 85 & 79.5 & 2.7 \\
\hline Length of antennal s. VIII & $81-84$ & 75 & 85 & 78.2 & 4.6 \\
\hline Width of antennal s. I & $51(70)$ & 45 & 55 & 48.6 & 3.9 \\
\hline Width of antennal s. III & $48-50$ & 45 & 50 & 47.3 & 2.6 \\
\hline Width of antennal s. IV & $48-51$ & 40 & 50 & 45.0 & 1.8 \\
\hline Width of antennal s. VIII & $23-24$ & 20 & 25 & 20.5 & 1.5 \\
\hline Length of inner sense cone on antennal s. III & $16-19$ & 25 & 30 & 26.4 & 2.3 \\
\hline Length of outer sense cone on antennal s. III & 20 & 25 & 35 & 28.9 & 3.5 \\
\hline Length of inner sense cone on antennal s. IV & $20-24$ & 20 & 30 & 27.3 & 3.4 \\
\hline Length of outer sense cone on antennal s. IV & $22-24$ & 27.5 & 35 & 30.5 & 1.9 \\
\hline Length of prothorax & $285(260)$ & 175 & 225 & 213.2 & 18.6 \\
\hline Width of prothorax & $500(525)$ & 375 & 475 & 457.3 & 34.7 \\
\hline Length of anteroangular setae & $48-54$ & 45 & 75 & 54.1 & 10.2 \\
\hline Length of mediolateral setae & $51-57$ & 15 & 55 & 44.5 & 14.9 \\
\hline Length of posteroangular setae & $102-108$ & 110 & 150 & 126.4 & 12.0 \\
\hline Length of epimeral setae & $102-108(122)$ & 110 & 135 & 122.7 & 8.8 \\
\hline Length of pterothorax & 405 & 460 & 550 & 483.2 & 31.4 \\
\hline Width of pterothorax & $570(525)$ & 485 & 665 & 611.4 & 59.6 \\
\hline Length of wing & 30 & 1020 & 1400 & 1132.3 & 110.3 \\
\hline Length of pelta & $143(132)$ & 110 & 145 & 130.5 & 11.7 \\
\hline Width of pelta & $286(282)$ & 200 & 250 & 230.5 & 20.0 \\
\hline Length of D1 on s. IX & $167(181)$ & 190 & 225 & 208.2 & 11.0 \\
\hline & & & & \\
\hline
\end{tabular}


Table 2. Continued.

\begin{tabular}{|l|c|c|c|c|c|}
\hline \multicolumn{1}{|c|}{ Characteristics } & H (P) & \multicolumn{4}{c|}{ Own data } \\
\cline { 3 - 7 } & & Min. & Max. & Aver. & \pm SD \\
\hline Length of D2 on s. IX & $200-205$ & 205 & 260 & 232.7 & 17.2 \\
\hline Length of D3 on s. IX & $(214)$ & & & & \\
\hline Length of tube & $182(167)$ & 175 & 250 & 223.6 & 22.3 \\
\hline Width of tube at base & $272(256)$ & 230 & 295 & 267.7 & 30.6 \\
\hline Width of tube at tip & $114(124)$ & 105 & 130 & 115.0 & 10.7 \\
\hline
\end{tabular}

\section{DISCUSSION}

In Norway KoBRo \& SOLHEIM (2002) collected both micropterous and macropterous forms of $\mathrm{H}$. carpathicus from dead birch (Betula pendula). Branches of birch were infested with Pseudospiropes longipilus (CORDA, 1837) HOLUBOVA-JECHOVA, 1973, the common fungus of that tree (BROWN et al. 2008). Those authors suggested that H. carpathicus forages on this fungus. Using Berlese funnels they obtained almost three thousand specimens, both males and females. They supposed that the tree had been inhabited by this species for several years. H. carpathicus was found sporadically on Picea abies and Pinus sylvestris LinNAeUs, 1753 (KoBRo \& RAFOss 2006). In Finland it was caught in window traps deployed on dead aspen (Populus tremula LinNaEUs, 1753) trees (KeTtunen et al. 2005). In Germany (Hessen, Vogelsberg Mts.) single specimens of H. carpathicus were caught several times in 1990 and 1991 in eclectors on the trunks of dead beech trees (ZUR STRASSEN 1994). During our research we found this species in both coniferous (the Białowieża NP) and deciduous forests (the Bieszczady NP), in the latter in traps hung on different trees - Betula pendula, Picea abies, Fagus sylvatica and Larix decidua.

The concealed lifestyle and dispersed occurrence of mycophagous thrips is a reason why they are difficult to find in their natural habitat. Populations of fungivorous thrips species usually remain in the same place and produce mainly apterous or brachypterous forms until the habitat is exhausted of the fungi. A larger proportion of macropterous specimens was recorded when the abundance of food decreased or the population density increased (KOBRO \& RAFOSS 2006, and observations made by the first author while rearing Hoplothrips pedicularius (HALIDAY, 1836)). The winged specimens caught in the screen traps in the Białowieża Forest and in the Bieszczady Mts. were probably migrating forms from populations living on the dead wood in the vicinity of the traps. 
In his description of the new species from Slovakia PELIKÁN (1961) wrote that the female (holotype) was apterous, but in listing the features of the pterothorax he stated that the wings were reduced to small pads $(30 \mu \mathrm{m}$ long). Moreover, the apterous forms are devoid of ocelli but these were present in the holotype and measured $18 \mu \mathrm{m}$. KовRO $\&$ RAFOSS (2006) referred to the form with substantially reduced wings as the micropterous form. During our study we collected only females with fully developed wings and ocelli (Fig. 1; Table 2).

Compared to the data given by PELIKÁN (1961) in his species description, some measurements of body parts and setae observed in the macropterous form differed from the micropterous holotype. The average total body length of macropterous specimens was greater than that of the holotype but less than that of the macropterous forms collected in Norway by KoBRo \& RAFOSS (2006). Those authors selected 13 characters which are useful for the identification of Hoplothrips species. The length of the mediolateral seta on the pronotum is a key feature: it was $51-57 \mu \mathrm{m}, 44.5 \mu \mathrm{m}$ (average), and $60 \mu \mathrm{m}$ in the Slovakian, Polish and Norwegian specimens, respectively. In our materials this feature was highly variable, with values between 15 and $55 \mu \mathrm{m}$ (Fig. 5; Table 2). The ratio between the distance of D1 setae on abdominal segment IX and the width of the tube basis is a key character distinguishing H. carpathicus from H. unicolor VUILLET, 1914: it is below one in the former and above one in the latter species. However, the first value was not measured by PELIKÁN in the holotype (Fig. 2; Table 2). Moreover, in the former species seta D1 is at most equal to the length of the tube, whereas in the latter it is longer than the tube (ZUR STRASSEN 1994).

The presence of two sense cones on antennal segments III and IV is a descriptive characteristic of $H$. carpathicus, but among the specimens studied a few had three (two longer and one short) sense cones on segment IV (Fig. 3). ZUR STRASSEN (1994) also observed the variability of this feature in specimens collected in Germany: the wingless forms had two and winged forms three sense cones on this segment. KOBRO \& RAFOSS (2006) in their identification key used the formulation "almost always two large sense cones on antennal segment IV", which may suggest that they noticed this variability in Norwegian specimens as well.

To date, apart from Norway, Finland, Germany and Poland, where H. carpathicus was caught at a few sites and in larger numbers, this species has been recorded only once from single samples in such countries as Slovakia, Sweden, Ukraine and Montenegro (Fig. 6) (PELIKÁN 1961, DyADEChKo 1964, ZUR STRASSEN 1994, SCHLIEPHAKE 2001, VASILIUOromulu et al. 2001, KetTunen et al. 2005, Kobro \& RAFOSS 2006, KetTunEN 2008, FEDOR et al. 2012). Although this species occurred in large numbers in Norway, it was found sporadically (KoBRO \& SOLHEIM 2002). In Germany it was placed on the Red List with the category endangered (EN) (SCHLIEPHAKE \& ZUR STRASSEN 1998). In Scandinavia 
and in the Białowieża NP $H$. carpathicus was recorded most often in coniferous forests, while in the Bieszczady NP and the other countries mainly from beech forests. Our use of screen traps in the Białowieża NP and the Bieszczady NP yielded $H$. carpathicus at several sites over a period of several years, indicating that this species is a constant constituent of the decaying-wood fauna in our study areas. The data given in the literature and the one added to as a result of our studies, confirm the boreal-montane range of $H$. carpathicus.

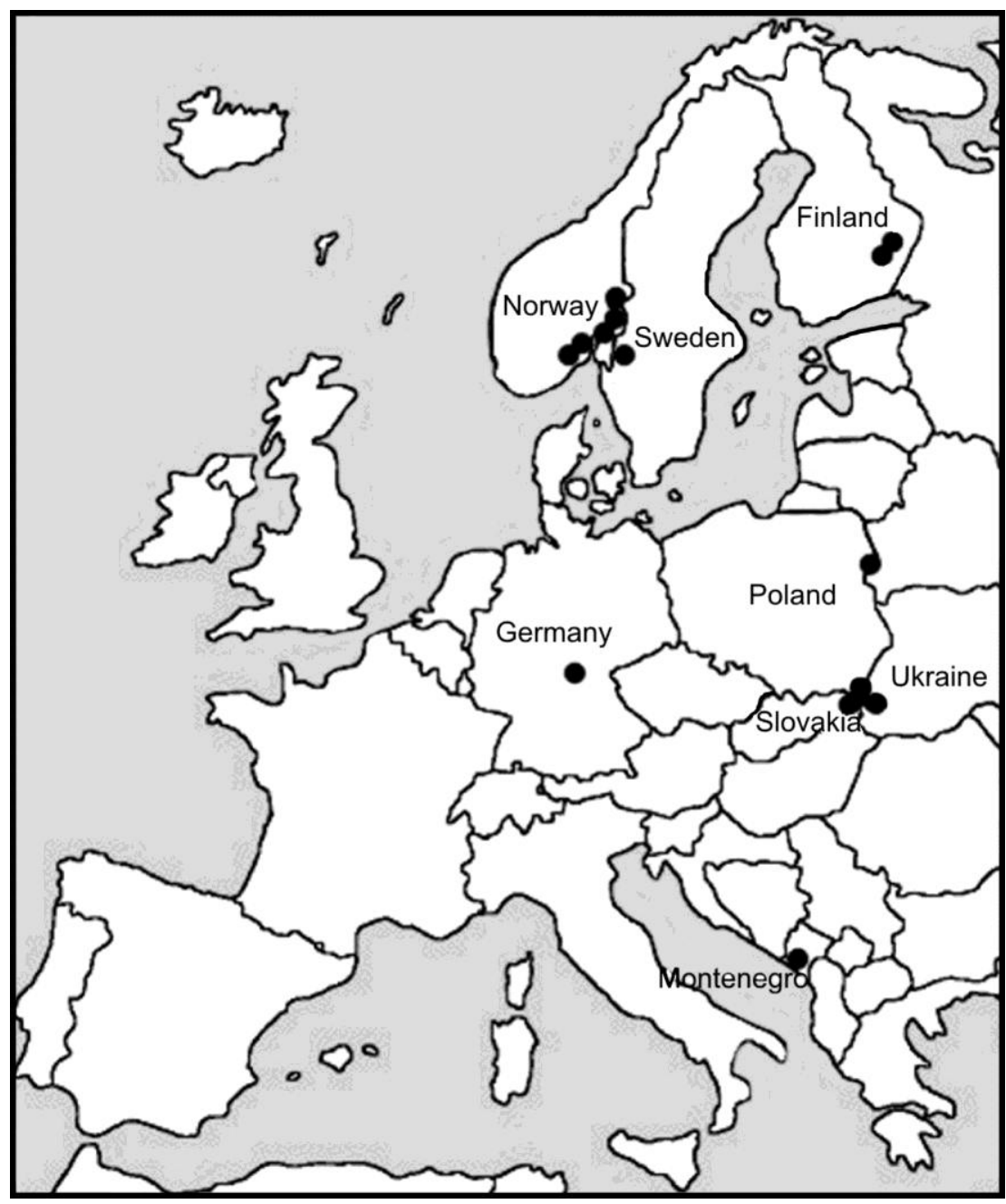

Fig. 6. Distribution of Hoplothrips carpathicus in Europe. 


\section{REFERENCES}

Braun U., Heuchert B., Brackel W. 2008. Pseudospiropes longipilus on Lepraria sp. a hyphomycete imitating a lichenicolous habit. Herzogia 21: 235-238.

CRESPI B.J. 1986. Territoriality and fighting in a colonial thrips, Hoplothrips pedicularius, and sexual dimorphism in Thysanoptera. Ecological Entomology 11(2): 119-130.

DyAdEChKo N.P. 1964. Thrips, or fringewinged insects (Thysanoptera) of the European part of the USSR. Urozhai, Kiev. (in Russian)

Fedor P.J., Doričová M., Masarovič R., Sierka W. 2012. Thrips (Thysanoptera) of Slovakia. Comenius University, Bratislava. (in Slovak)

GuTOWSKI J.M., KRZYSZTOFIAK L. 2005. Directions and intensity of migration of the spruce bark beetle and accompanying species at the border between strict reserves and managed forests in north-eastern Poland. Ecological Questions 6: 81-92.

KeTtUNEN J. 2008. Check-list of Finnish Thysanoptera. Internet: http://biolcoll.utu.fi/hemi/tyoryhma/ Check-list_of_Finnish_Thysanoptera.pdf. (access 21.02.2015)

Kettunen J., Kobro S., MartiKainen P. 2005. Thrips (Thysanoptera) from dead aspen (Populus tremula) trees in Eastern Finland. Entomologica Fennica 16(4): 246-250.

Kobro S., RAFoss T. 2006. Identification of adult males and females of Hoplothrips species (Thysanoptera: Tubulifera) known from Norway, and some deduction on their life history. Entomologica Fennica 17(2): 184-192.

Kobro S., SolHeim H. 2002. Hoplothrips carpathicus PeLIKÁN, 1961 (Thysanoptera, Phlaeothripidae) in Norway. Norwegian Journal of Entomology 49(2): 143-144.

Kucharczyk H. 2007. Thrips (Thysanoptera) [in:] W. Bogdanowicz, E. Chudzicka, I. Pilipiuk, E. SKIBIŃSKA (eds). Fauna of Poland. Characteristics and checklist. Vol. II. Arthropoda pro parte, Insecta pro parte (Coleoptera, Hemiptera, Hymenoptera, Lepidoptera excluduntur), Entognatha. Museum and Institute of Zoology of the Polish Academy of Sciences, Warsaw, 391-398. (in Polish)

Mound L.A., KiBBy G. 1998. Thysanoptera - an identification guide. CAB International, Wallingford.

Mound L.A., Morison G.D., Pitkin B.R., PALMer J.M. 1976. Handbooks for the identification of British insects, vol. 1. Thysanoptera. Royal Entomological Society of London, London.

Mound L.A., WALKer A.K. 1986. Fauna of New Zealand. Number 10, Tubulifera (Insecta: Thysanoptera). DSIR, Wellington.

PelikÁn J. 1961. New species of Thysanoptera from Czechoslovakia - IV. Acta Societatis Entomologicae Cechosloveniae 58(1): 60-70.

PRIESNER H. 1964. Bestimmungsbücher zur Bodenfauna Europas, 2. Ordnung Thysanoptera (Fransenflügler, Thripse). Akademie-Verlag, Berlin.

SCHLIEPHAKE G. 2001. Verzeichnis der Thysanoptera (Fransenflügler) - Physopoda (Blasenfüße). [in:] B. Klausnitzer (ed.). Entomofauna Germanica. Band 5. Verzeichnis der Archaeognatha, Zygentoma, Ephemeroptera, Odonata, Plecoptera, Dermaptera, Mantodea, Ensifera, Caelifera, 
Thysanoptera und Trichoptera Deutschlands. Entomologische Nachrichten und Berichte, Beiheft 6: $91-106$

SchliephaKe G., Klimt K. 1979. Die Tierwelt Deutschlands, Teil 66. Thysanoptera, Fransenflügler. Gustav Fischer Verlag, Jena.

SCHLIEPHAKe G., ZUR STRASSEN R. 1998. Rote Liste der Fransenflügler (Thysanoptera). Schriftenreihe für Landschaftspflege und Naturschutz 55: 250-251.

Tree D.J., Mound L.A., WALTER G.H. 2010. Fungal spore-feeding by adult and larval Mecynothrips hardyi (PRIESNER) (Thysanoptera: Phlaeothripidae: Idolothripinae). Journal of Natural History 44(5-6): 307-316

VASIliu-OrOMUlu L., ZUR STRASSEN R., LARSSON H. 2001. The systematic revision of Thysanoptera species from the Swedish fauna and their geographical distribution. Entomologica Romanica 6: $93-101$

VIERBERGEN G. 2013. Thysanoptera. [in:] Fauna Europaea version 2.6.2. Internet: http://www. faunaeur.org. (access 21.02.2015)

ZUR STRASSEN R. 1994. On some rare fungivorous phlaeothripid Thysanoptera (Insecta) from Germany and Sweden. [in:] R. ZUR STRASSEN (ed.). Proceedings of the Workshop on Thysanoptera at Bejing, China, and of the Symposium on Thysanoptera at Halle, Germany, both in 1992. Courier Forschungsinstitut Senckenberg 178: 115-119.

Received: 18 March 2015

Accepted: 10 April 2015 